\title{
Work values in tourism: Past, present and future
}

\author{
Emmanouil Papavasileiou ${ }^{\mathrm{a}}$, Sean Lyons ${ }^{\mathrm{b}}$, Gareth Shaw $^{\mathrm{c}}$, Anthimos Georgioud \\ aUniversity of Portsmouth Business School, UK \\ ${ }^{b}$ Guelph University, Canada \\ 'University of Exeter, UK \\ dInternational Management Institute Switzerland, Switzerland
}

Keywords: Work values, Japan, Second-order, Confirmatory factor analysis, Reconceptualisation, Validation

\begin{abstract}
Although work values are important psychological variables in organisations, little research has been done to clarify the way in which work values are conceptualised. We address the need within the field to understand and engage with wider debates within social science literature by presenting an up-to-date review of work values in tourism research and a synthesis of paradigms pertaining to established value models and theories. We reconceptualise work values as a second-order projection of intrinsic, extrinsic, prestige and social types of values in the work settings of tourism. We then test the conceptual validity of this model through exploratory and confirmatory factor analysis using data from Japanese tourism workers.
\end{abstract}

\section{Introduction}

For decades, organisational scholars have applied the construct of values to understand personal identification in organisations (Ashforth, Schinoff, \& Rogers, 2016). Unfortunately, despite many advances, the work values literature lacks synthesis, making it challenging to apply to practical settings. Leuty and Hansen (2011) concluded that " Little work has been completed to summarize and organize different conceptualisations of work values (p. 381) . . [and although] the current study provided much needed examination of work values, future research can continue to develop our understanding of the construct" (p. 389).

The application of work values to tourism research goes back to the foundational work of Abraham Pizam and associates, which examined the work values profiles of tourism and hospitality students (Neuman et al., 1980; Pizam \& Lewis, 1979; Pizam, Reichel, \& Neumann, 1980). The subject resurfaced when Mok, Pine, and Pizam (1998) and Wong and Chung (2003) reported the work value profiles of hotel workers in Hong Kong. Chen and associates twice revisited this theme in the USA, first identifying the work value profiles of three generations of hospitality workers (Chen \& Choi, 2008) and then comparing the work values profiles of hospitality workers to hospitality students (Chen \& Tesone, 2009). Generational differences in work values were also reported by Gursoy, Chi, and Karadag (2013), using a sample of frontline and service contact employees. Meanwhile, Chu (2008), Wong and Liu (2009) and White (2006) provided evidence of tourism and hospitality students' work value profiles from Taiwan, Hong Kong and a multinational context, respectively.

Unfortunately, each of these studies utilised a different work values typology, an approach that has stymied confusion in work values research within a variety of disciplines, such as management (Gehman, Trevino, \& Garud, 2013), vocational behaviour (Leuty \& Hansen, 2011) and organisational behaviour (Lyons, Higgins, \& Duxbury, 2010). When faced with a body of literature that is mature, but fractured, it is beneficial to critique, synthesize, update and add missing pieces in order to provide 
a way forward for future developments (Tribe \& Liburd, 2016). Our objective is to make such a contribution to the literature concerning work values in tourism. To accomplish this, we follow the steps for conceptual research identified by Xin, Tribe, and Chambers (2013) and Tribe and Liburd (2016), providing both quantitative (volume and context) and qualitative aspects (comparison of definitions and typologies, conceptual gaps, synthesis and reflection). We begin with an outline of the search strategy and a brief description of the research context, focusing on the size of the samples of the studies under review as well as their occupational and cultural identities. The features recurrently mentioned in the definitions of work values are provided and the method used to derive the typologies is examined. Emphasis is placed on the assessment utilised to extract the work values data, the method of analysis and the derived number of types.

Our analysis reveals a significant gap between the dominant conceptualisation of work values as expressions of values in the work setting and the derived typologies. To address this gap, a series of paradigms pertaining to evolved values model and theories are then presented, reflecting on (a) the meaning of general life values and value systems; (b) the relationship of work values vis-à-vis general life values; (c) the types of work values; and (d) the relationship between the types.

Based on our review, we reconceptualise work values as a second-order expression of intrinsic, extrinsic, prestige and social values in the work setting of tourism. Extending earlier reconceptualisation approaches, such as Reisinger and Steiner (2006) in object authenticity, Russo and Segre (2009) in destination and property regimes and Tribe and Liburd (2016) in tourism knowledge systems, we provide evidence of conceptual validity by means of exploratory factor analysis (EFA) and confirmatory factor analysis (CFA). The analysis is based on data from the $2008^{1}$ Working Persons Survey (WPS) in Japan. Our conceptualisation reveals a better fit when compared against structurally competing models (i.e., all items loaded into one factor and a first-order equivalent) as well as alternative theoretically derived models (i.e., second-order with three factors and an intrinsic/extrinsic dichotomisation).

\section{Work values in tourism research}

\section{Search strategy}

Our search strategy was designed to find empirical quantitative studies about values related to the supply element of tourism, the human capital (i.e., students) and the labour force. The search period was from February 1979 - the year Pizam and Lewis's seminal article "Work Values of Hospitality Students" was published - to December 2015. We first identified relevant published studies, using Scopus and ISI Web of Knowledge (WoK), the leading online international databases for tourism publications (Figueroa-Domecq, Pritchard, Segovia-Pérez, Morgan, \& VillacéMolinero, 2015). The search terms applied in all cases were "tourism", "hospitality", "leisure", "values" and "work values". Relevant studies were identified by examining their title, abstract and the full text (Phillips \& Moutinho, 2014). Studies that focused on the role of values in the production element of tourism, such as tourist shopping behaviour (Choi, Heo, \& Law, 2015) were excluded. Similarly, papers with a qualitative research focus such as Gursoy, Maier, and Chi's (2008) in-depth focus group discussion study of work values and generational gaps of US hotel workers were excluded.

The first search identified 14 empirical studies of work values published in six academic journals (i.e., Annals of Tourism Research; International Journal of

\footnotetext{
${ }^{1} 1$ We use the 2008 data because later years do not include the necessary assessment of work values.
} 
Hospitality Management; International Journal of Contemporary Hospitality Management; Journal of Hospitality and Tourism Research; The Service Industries Journal; Tourism Management). Second, the search of previous reviews within the wider organisational studies such as Parry and Urwin (2011) resulted in the inclusion of Chen and Choi's (2008) study. Third, using Google Scholar, we searched the studies that cited the fifteen previously identified cases. This procedure added three papers (Chen \& Tesone, 2009; Koroglu \& Gezen, 2014; Wong \& Liu, 2009) resulting in a total sample of eighteen empirical tourism studies of work values published from 1979 to 2014.

\section{A two wave history}

In the late-1970s and early-1980s, tourism scholars were amongst the first researchers to provide distinct work value profiles within the organisational context. Despite this important early contribution concerning the motivational impacts of work values, further research in tourism stagnated for almost two decades. The partial decoupling in the 1980s and 1990s of tourism research from that in general management and social sciences (Shaw \& Williams, 2009) and the relative neglect of research, at that time, in the area of tourism supply (Baum, Kralj, Robinson, \& Solnet, 2016; Ladkin, 2011) probably played a role in the decline in empirical research. However, the phenomenal growth of tourism employment over the last 20 years has raised concerns about people resourcing, which has been recognised as the most challenging issue for practitioners in the industry (Baum et al., 2016; Ladkin, 2011). As the world of work has evolved, due to changes imposed by political, economic, socio-cultural and technological forces, so have the expectations towards work in tourism (Baum et al., 2016; Solnet, Kralj, \& Baum, 2015).

In response to these challenges, tourism scholars have recently extended the early work of Pizam and associates, further exploring the use of work values in screening new applicants and improving the motivation of existing employees. The volume of work values studies within tourism has more than doubled in recent years; we identified only five studies published between 1979 and 1998, compared to thirteen between 2000 and 2014. This increased attention has provided significant evidence regarding the work value profiles of current and future employees across a variety of cultural and occupational contexts.

\section{Rich context}

The majority of studies shown in Table 1 were conducted in the United States (6), Taiwan (4) and Hong Kong (3). Australia, Turkey and Slovenia, were also included, each from one study whilst White $(2005,2006)$ conducted studies with multinational samples. The size of the samples varied from small, ranging from 51 to 190 participants (5 studies), to medium with 218 to 398 participants (7 studies) and large with 511 to 1220 participants (6 studies). Participants were mostly students (11 studies), but Chen and Tesone (2009) compared students to practitioners. The occupational context of practitioner focused studies (6) varied from frontline hotel workers and managers in restaurants, to tour guides and travel agency administrative staff and from workers in theme parks and food services to the convention/meeting and planning industry.

\section{Common conceptualisation}

The definitions included in Table 1 suggest three recurrent themes about work values: (a) they are expressions of general life values in the work setting representing (b) mode of behaviours or outcomes that (c) organise and guide current and/or future employees' decisions in the work setting. In particular, it is generally assumed that 
values, as expressed at the general life level, and values expressed in the work setting are interrelated. Gursoy et al. (2013, p. 41) is the sole study to describe this relationship conceptually, arguing that values have a particular cognitive structure that produces a structural similarity between general values and work values.

A distinction can also be made between studies that conceptualise values as modes of behaviour (e.g., accomplishing) and those that describe values as outcomes (e.g., the feeling of accomplishment related to tourism work). Some authors (i.e., Koroglu \& Gezen, 2014; Liang, 2012; Mok et al., 1998; White, 2005, 2006) draw on Rokeach's (1973) seminal work, defining general life values as, enduring perspectives of what is fundamentally right or wrong in the work domain, or beliefs that instruct people on how they should behave at work. This view depicts work values as people's internalized interpretations about how they "should" or "ought" to behave at work. Other researchers (e.g., Chen \& Tesone, 2009; Chu \& Chu, 2013; Gursoy et al., 2013) describe work values as important outcomes that people seek to satisfy through working and which affect the decision to choose and continue with a specific work environment.

\section{Multiple typologies}

Table 1 illustrates a range of conceptual typologies incorporating between two and fifteen work value types, with four types being the most frequent (4 studies). Pizam et al. (1980) and Neuman, Pizam, and Reichel (1980), used Super's Work Values Inventory (SWVI; Super, 1970) and principal component analysis to present a fourcomponent typology (i.e., self-expression, work conditions, status and altruistic). Similar four-type conceptualisations were used by White (2006) and Chen and Choi (2008) (Table 1). By contrast, other studies that used the same assessment and the same analytical method as above, such as Chen and Tesone (2009) and Chu (2008) derived a three-component typology (see Table 1). Mok et al. (1998) and Wong and Chung (2003) reported a five and a six-component typology, respectively, using both Hofstede's Value Survey Model (1980) and principal component analysis (Table 1). Notably, although Wong and Liu (2009) and Liang (2012) used different inventories to assess work values (i.e., Super (1970) versus deVaus and McAllister (1991)) and different methods to analyse the data (i.e., hierarchical cluster analysis versus CFA), they both derived a two-type intrinsic/extrinsic typology. The largest number of work value types were derived by Gursoy et al. (2013) and Koroglu and Gezen (2014) with seven and fifteen types of work values, respectively. Table 1, shows some studies, such as Pizam and Lewis (1979), Ross (1992) and White (2005) reported work value profiles based on the individual items, without proceeding further to the construction of conceptual typologies. In addition, Bizjak, Knezevic and Cvetreznik (2011) relied on the five higher-order types of the Value Scale (Super \& Nevill, 1986) derived from Vizek-Vidovic, Kulenovic, Jerneic, \& Sverko (1984) rather than analysing individual items and Chu and Chu (2013) similarly analysed the four-types of the Work Values Survey (Ros, Schwartz, \& Surkiss, 1999). Furthermore, Chen, Hei-Lin Chu, and Wu's (2000) cluster analysis of work values scores aimed at clustering cases instead of variables, therefore the reported typology of work value profiles among hospitality students: achievement seekers; income movers; and liberal workers.

\section{Conceptual gaps}

Our analysis reveals that there is common agreement on the conceptualisation of work values as expressions of values in the work setting, yet the underlying psychological mechanisms remain largely unexplored. Unfortunately, most of the 


\begin{tabular}{|c|c|c|c|c|}
\hline Sudies & Definition & Sample & Inventary & Typology \\
\hline $\begin{array}{l}\text { Pizam \& Lewis, } \\
1979\end{array}$ & 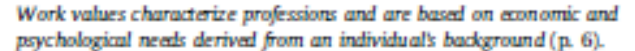 & US, 171 students & SWMi; Super, 1970 & Original Sale \\
\hline $\begin{array}{l}\text { Neuman et al, } \\
1980\end{array}$ & & US, 218 students & swl & Self-Expressian; Wark Conditions; Status and Altruistic \\
\hline Pizam et al, 1980 & N/A & US, 190 students & swl & Self:Expression; Work Conditions; Status and Altruistic \\
\hline Rass, 1992 & 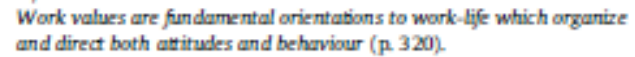 & $\begin{array}{l}\text { Austral i2,594 high } \\
\text { school students }\end{array}$ & WAPS; Pryor, 1983 & Original Saale \\
\hline Maket al, 1998 & 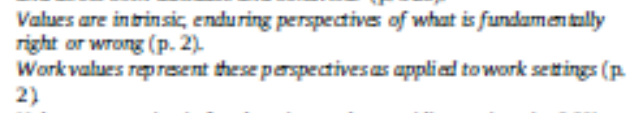 & $\begin{array}{l}\text { Hang Kang, } 120 \\
\text { Chinese ethric hotel } \\
\text { employees }\end{array}$ & VSM; Hofitede, 1980 & $\begin{array}{l}\text { Task Characteristis; Incme Oranization; Oual ity of life, } \\
\text { Working Relations; Cammunity }\end{array}$ \\
\hline Gen at al, 2000 & Valuess act as criteriy far choosing goals or guiding actions ( $p 360)$ & Taiwan 311 students & swil & Adtieverment Serkess'; Income movers; Liberal workers \\
\hline $\begin{array}{l}\text { Wang \& }{ }_{20} \text { Chung. } \\
2003\end{array}$ & Values are enduring beliefs (p. 67 ) & $\begin{array}{l}\text { Hang Kang } 152 \\
\text { manugers in Chinese } \\
\text { hotel restaurants }\end{array}$ & VSM & 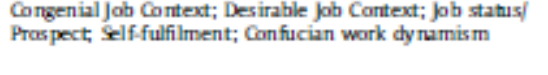 \\
\hline White, 2005 & $\begin{array}{l}\text { Values are belief that are experienced by an individual as standarts } \\
\text { that in sorect how they should function (p. 221) }\end{array}$ & $\begin{array}{l}\text { Mul tinational, } 276 \\
\text { students }\end{array}$ & swl & Original Sale \\
\hline White, 2006 & $\begin{array}{l}\text { Vallues are be liefs that are experienced by an intividual as standards } \\
\text { that in sfruct how they should function (p. 221). }\end{array}$ & $\begin{array}{l}\text { Mult tinational, } 562 \\
\text { students }\end{array}$ & swl & $\begin{array}{l}\text { Confort-Independent; Affiliation; Simulation; } \\
\text { Adtievement }\end{array}$ \\
\hline С̆ $2008^{\prime \prime}$ & $\begin{array}{l}\text { Work values are important and valuable outcome that individuals } \\
\text { derive from work (p. 321). }\end{array}$ & Taiwan 511 students & swi & Tangible Rewards; liberal Spirit; Self-fulfilment \\
\hline Chen \& Chai, 2008 & 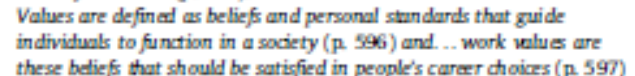 & $\begin{array}{l}\text { US, } 398 \text { hospitality } \\
\text { practitioners }\end{array}$ & swl & $\begin{array}{l}\text { Confort and Seaurity; Personal Growth; Professional } \\
\text { Growth; Wark Environment }\end{array}$ \\
\hline $\begin{array}{l}\text { Chen \& Tesane, } \\
2009\end{array}$ & 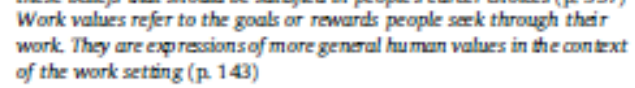 & $\begin{array}{l}\text { US, } 828 \text { students and } \\
398 \text { practitioners }\end{array}$ & swi & Cenesal; Marugement; Hospitality \\
\hline Wong \& Liu, 2009 & 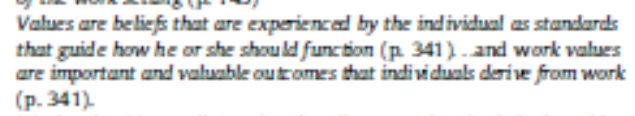 & $\begin{array}{l}\text { Hang Kang } 566 \\
\text { tourism students }\end{array}$ & swil & Int insic; Extrinsic \\
\hline 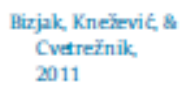 & $\begin{array}{l}\text { Work values' is ucually weed to describe general and relatively stable } \\
\text { goats tha pepple try to reach throught work (p.851) }\end{array}$ & $\begin{array}{l}\text { Sloveniz, } 51 \text { tourism } \\
\text { students }\end{array}$ & vs; Super \& Nevill, 1986 & $\begin{array}{l}\text { Self actualisation; Avanturistic; Social arientation; } \\
\text { Individual orientation; Utilitarian arientation }\end{array}$ \\
\hline liang, 2012 & 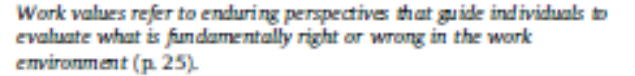 & $\begin{array}{l}\text { T2iwan, } 306 \text { hotel } \\
\text { workers }\end{array}$ & $\begin{array}{l}\text { de Vaus \& McAllister, } \\
1991\end{array}$ & Int insic, Extrinsic \\
\hline Chu and Chu, 2013 & $\begin{array}{l}\text { Work valus refor to exp rescions of in dividual goals in work settings to } \\
\text { choose and continue with a spacific work emvironment }\end{array}$ & $\begin{array}{l}\text { Taiwan, } 381 \text { tourism } \\
\text { professianak }\end{array}$ & Raset al, 1999 & Intr insic, Extrinsic, Prestige, Sacial \\
\hline Gurscy et al, 2013 & 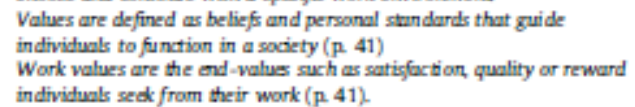 & US, 717 hotel workers & $\begin{array}{l}\text { 25-itens generated } \\
\text { from a series of focus } \\
\text { group meetings }\end{array}$ & $\begin{array}{l}\text { Leadership; Wark Centrality; Work-life Hil ance; Power; } \\
\text { Non-Campl iance; Recognition; Technology Chull lerge }\end{array}$ \\
\hline $\begin{array}{l}\text { Koroglu and } \\
\text { Ceren, } 2014\end{array}$ & $\begin{array}{l}\text { Values are intrinsic, enduring perspectives of what is fundementally } \\
\text { right ar wrong. ( } \mathrm{p} .254 \text { ) } \\
\text { Work values represent these perspectives as appliad to work settings: } \\
\text { (p. } 254 \text { ) }\end{array}$ & $\begin{array}{l}\text { Turkey, } 397 \text { t turism } \\
\text { students }\end{array}$ & WVS Pilavcy. 2007 & 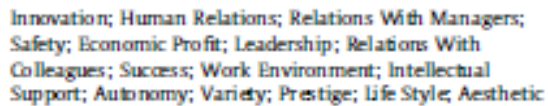 \\
\hline
\end{tabular}

Source: author.

SWVI - Super's Work Values Inventory; WAPS: Work Aspect Preference Sale; VSM - Values Survey Model; VS- Values Survey; WVS - Work val ues Sale

-." The analysis of the 45 items did not conform to the 15 work values propased by Super (1970) 
endeavours to construct a conceptual typology for work values were based on inductive approaches, rather than being derived from theory. Although inductive analyses are useful as exploratory evidence, they are fundamentally data driven and open to interpretation, rather than guided by a priori theoretical positions. As a result, there is disagreement on the meaning and the number of types that comprise the work values domain, making it difficult to extract firm conclusions from the findings. Table 1 , shows a number of studies using the SWVI reported very different factor structures (cf. Chen \& Choi, 2008; Chen \& Tesone, 2009; Chu, 2008; Pizam et al., 1980).

This confusion is an obstacle to greater understanding of work values and their role in research and practice within tourism. A field of research only advances through the testing and refinement of theoretically driven models (Colquitt \& Zapata- Phelan, 2007). We argue that although there is scholarship on the deeper features of the work values conceptualisation such as the content of values, the relationship between work values and general life values, the types of work values and the relationship between these types, it is beset by debates and disagreements about the nature and meaning of work values and has not gained ground in tourism studies. Thus, a synthesis of this scholarship provides a fertile ground for a coherent framework in reconceptualising work values within tourism.

\section{Synthesis and reflection}

Over the past several decades, the study of individuals' attitudes and behaviours as value-driven responses has been an appealing concept in almost all social sciences. As a result, many conceptualisations of values have been theoretically articulated, with Schwartz's (1992) theory of basic human values representing the most comprehensive and up-to-date structure of values (Jin \& Rounds, 2012). Schwartz (1992, p. 4) summarised five features recurrently mentioned in the values literature; values (1) are concepts or beliefs, (2) pertaining to desirable end states or behaviours, (3) transcending specific situations, (4) guiding selection or evaluation of behaviour and events, and (5) are ordered by relative importance. These features provide a wider content to the meaning of values than the one identified by tourism studies and are all consistent with the presence of a value system, a stable meaning-producing superordinate cognitive structure (Rohan, 2000). It appears, therefore, that two critical features should be included in the extant conceptualisations of general life values in tourism studies: the ordering by relative importance feature and the transcendental nature of values.

The former feature is responsible for providing the basic - hierarchically organised architecture of what has been referred to as the "narrative mode" of human understanding (Rohan, 2000). The relative importance attributed to each aspect of life constitutes the individual's system of value priorities and is incorporated in all current theoretical models pertaining to value-related decision making and behaviours to explain how people make decisions (Ravlin \& Meglino, 1989; Lyons et al., 2010). Schwartz (1992) has schematically represented the value system as a hierarchical organised continuum of related motivations arrayed into four-high order types of values: openness to change; conservation; self-transcendence; and selfenhancement (Fig. 1-left). This model has been tested across 75 countries and 300 samples, providing strong support for the universality of the theorized content and the structure of values (see Davidov, Schmidt, \& Schwartz, 2008).

Although there is only one value system that individuals use to evaluate the general aspects of life, individuals are likely to have more than one social value system (Rohan, 2000). This quality of the value system is directly related to the second feature of values, which has been omitted by tourism scholars. 


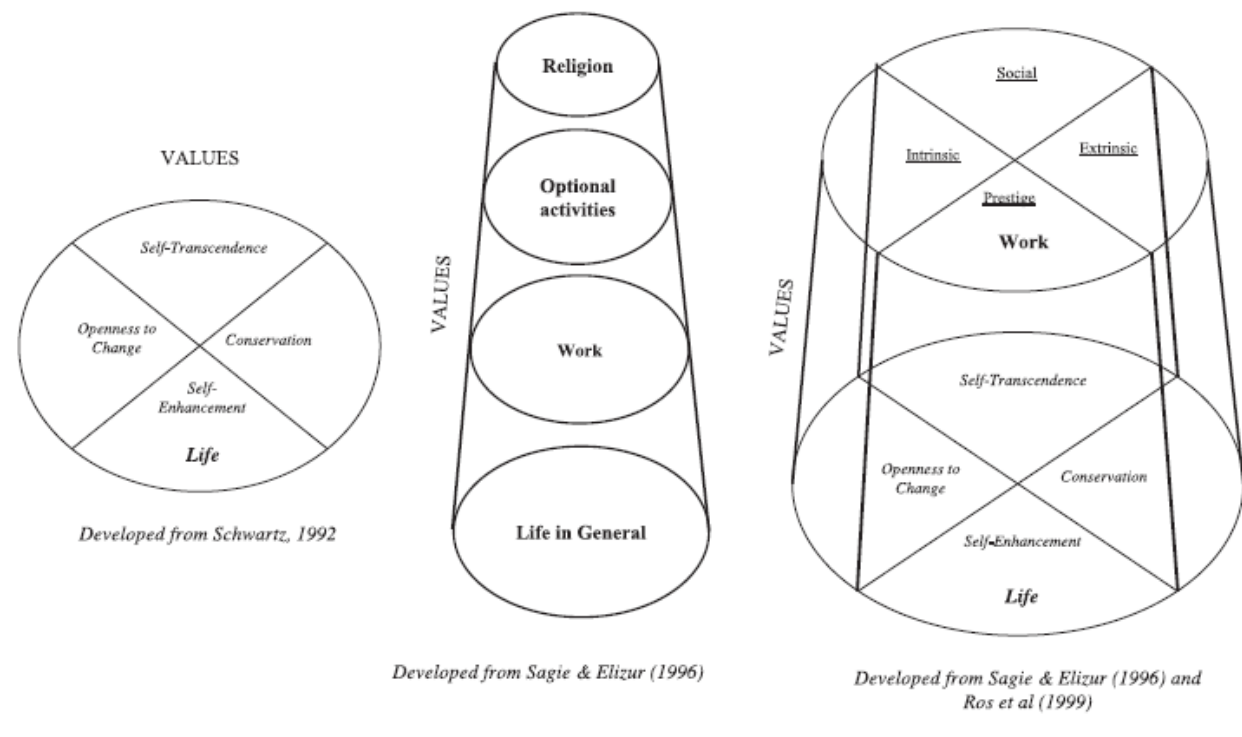

Fig. 1. Models of general life values and work values.

The transcendental nature of values allows people to project their unique values system for evaluating aspects of life in more specific domains such as politics, religion, sports, education and work (Jin \& Rounds, 2012). Based on this particular feature of values, Sagie and Elizur (1996) demonstrated that work values, religious values and political values emerge from the projection of general life values in to the life domain of work, religion and politics, respectively. A graphical representation of this theoretical model of values is presented in Figure 1 (middle). This emerging theoretical model corroborates Gursoy et al.'s (2013) assumption that values have a particular cognitive structure that produces a structural similarity between general values and work values.

In terms of the relationship between the types of work values in the derived typologies, most their unique values system for evaluating aspects of life in more specific domains such as politics, religion, sports, education and work (Jin \& Rounds, 2012). Based on this particular feature of values, Sagie and Elizur (1996) demonstrated that work values, religious values and political values emerge from the projection of general life values in to the life domain of work, religion and politics, respectively. A graphical representation of this theoretical model of values is presented in Figure 1 (middle). This emerging theoretical model corroborates Gursoy et al.'s (2013) assumption that values have a particular cognitive structure that produces a structural similarity between general values and work values.

In terms of the relationship between the types of work values in the derived typologies, most of the studies have utilised orthogonal rotations in their factor analytic methods to construct conceptual typologies of work values. Although the simplicity and conceptual clarity of orthogonal rotations may be appealing, there is an imposed restriction of uncorrelated factors on the derived conceptualisations (Hair, Black, Babin, \& Anderson, 2014, p. 137). This means that the types of work values represent rather discrete entities, contradicting Schwartz's basic tenet of values which posits that values "represents a continuum of related motivations, like the circular continuum of colours, rather than a set of discrete motivations" (Davidov et al., 2008, p. 424). Therefore, there is a substantial theoretical and empirical basis for expecting the general value types to be inter-correlated. Thus, tourism scholars should expect the types of work values to be also correlated with one another.

There are currently three approaches to classifying the various types of work values. First, self-determination theory dichotomises the domain of motivations into two 
contrasting types. Extrinsic motivation refers to the performance of an activity in order to attain some separable outcome. This contrasts with intrinsic motivation, which refers to undertaking an activity for the inherent satisfaction of the activity itself (Ryan \& Deci, 2000, p. 71). Intrinsic types of work values are more directly associated with the fulfilling of inherent psychological needs such as competence and independence, whilst extrinsic work values tap into material aspects of work, such as benefits, pay and job security (Jin \& Rounds, 2012).

The second perspective stems from Dawis and Lofquist's (1980) theory of work adjustment, which conceptualises work values as "second-order needs" in the work environment. Their typology includes six types of needs associated with the work environment organised into three second-order work values (work reinforcers): social (altruism and status), environment (safety and comfort) and self (achievement and autonomy).

The third paradigm is the adoption of Schwartz's (1992) basic value theory in the work setting as theoretically articulated and empirically validated by Ros et al. (1999). In this theoretical model, work values are posited to be conceptual parallels to the four higher-order types of general life values in Schwartz's (1992) values model: (1) intrinsic work values, which reflect the pursuit of personal growth (e.g., advancement, autonomy and independence in work), were related to openness to change values; (2) extrinsic work values, representing more concrete work outcomes (e.g., pay, security and comfortable work environment), related to conservation values; (3) social work values, which capture emotions, feelings and social experiences (e.g., esteem, social contribution and interpersonal work relationships), related to self-transcendence values; and (4) prestige work values, which refer to aspects of personal success and dominance over others (e.g., status, organisational image, authority and decisionmaking at work), related to self-enhancement values.

\section{Reconceptualising work values in tourism}

\section{Work values as second-order projections of values in the work setting of tourism}

Our reconceptualised model of work values system as a second-order projection of values in the work setting of tourism is presented in Fig. 1 (right). Based on Schwartz's theory of basic human values, we define values as implicit organisers of preferences about the capacity of the environment to satisfy our needs for survivor, functioning and social interaction. In addition, we consider the values system as a hierarchically ordered cognitive structure that comprises four high-ordered types: openness to change, conservation, self-transcendence and self-enhancement. Taking into consideration the transcendental nature of values, we assume that a structural similarity exists between the general life values system and the work values system, as evidenced by Sagie and Elizur (1996). Within this context, work values are conceptualised as expressions of general life values in the work setting and defined as implicit organisers of preferences about the capacity of the work environment to satisfy our needs for survivor, functioning and social interaction. Following the rule of parsimony, we further assume that the work values system could be represented as a second-ordered factorial structure of four high-ordered types: intrinsic, extrinsic, prestige and social. This extends Ros et al.'s (1999) emerging theoretical model of work values and corroborates the second-order nature of work values proposed by the theory of work adjustment. The proposed conceptualisation forms a meaningful and coherent whole for the deeper features of work values such as the relationship between general life values and work values (work values emerge from the projection of general life values in the work setting of tourism), the types of work values 
(intrinsic, extrinsic, prestige and social) and the relationship between the types (correlated in second-order structure).

\section{Procedure for testing the concept}

To test the second-order conceptualisation presented in Fig. 1 (right), we analysed secondary data from the 2008 WPS, a high-quality biennial survey (Holbrow, 2015) established in 2000 by the Recruit Works Institute. The WPS provides a detail picture of the employment conditions and attitudes towards work of employees living within a $50 \mathrm{~km}$ radius of the Tokyo metropolitan area (Tokyo, Kanagawa, Chiba and Saitama prefecture) (Toda, 2016). The sampling frame included employees aged 18 to 59 at the time of the study (i.e., 22 August to 9 September 2008), who had worked at least one day in the last week of July 2008. Participants were recruited using area probability sampling, based on repeated resampling within blocks until the desired sample size $(\mathrm{N}=6500)$ was reached (Toda, 2016).

The measure of work values incorporated in the 2008 WPS (i.e., Q.19 and Q.21) consists of 32 items related to aspects and outcomes of work (see Appendix). Although the conceptual framework underlying the measure has not been explicitly articulated by the Recruit Works Institute, these items are highly similar to those included in other popular measures of work values, such as the SWVI, the Work Values Survey (cf. Sagie \& Elizur, 1996), Ros et al.'s (1999) work values measure and the Lyons Work Value Survey (Lyons et al., 2010). As noted by Lyons et al. (2010, p. 974), work values are an organizing construct and as such, the precise nature of the items in any work values instrument is not particularly important, so long as the scale solicits importance ratings or rankings of a range of work aspects of sufficient breadth to represent the full work values domain. We compared the WPS items set against known conceptualisations of work values and judged that the items covered a sufficient range of work aspects to facilitate the testing of our model. The wording of the 2008 WPS work value items ask participants, no matter their previous or current employment, to rate the importance $(1=$ Very important, $5=$ Very unimportant, $6=$ No answer) of the 32 work-related outcomes.

As shown in Table 2, we divided the sample into two sub-samples based on their sector of employment. Our first subsample consisted of workers in tourism related sectors (i.e., Question 6, options 52, 51 and 35) and the second subsample comprised employees in all remaining sectors. Utilising IBM SPSS 22, the data from the nontourism sub-sample were analysed using EFA with maximum likelihood and oblique rotation, allowing the factors to be correlated (Hair et al., 2014; p. 96), as previously hypothesised. Fabrigar, et al. (1999, p. 282) note that when there is substantial theoretical for expecting the dimensions of a construct to be correlated with one another, oblique rotations provide a more accurate and realistic representation of how constructs are likely to be related to one another. Therefore, from a substantive perspective, the restriction of uncorrelated factors imposed by orthogonal rotations is, in such cases, unwarranted and may result in misleading outcomes. The derived pattern matrix was then used to construct a second-order conceptualisation which was tested on data from the tourism sector sub-sample using CFA in IBM AMOS 22 software.

\section{Exploratory factor analysis}

The option of "no answer" (at least in one of the 32 items) was detected in 79 cases, which were deleted from further analysis $(\mathrm{N}=5951)$. The assessment of normality revealed no items with a skew or kurtosis index greater than the cut-off values of $|3|$ or $|8|$ recommended by Kline (2011; p. 63). Furthermore, the Bartlett test of sphericity 
(70868.171; $\mathrm{p}=0.000)$ and the Kaiser-Meyer-Olkin measure of sampling adequacy $(\mathrm{KMO}=0.929)$ were in line with Hair et al.'s (2014; p. 103) recommendations for sufficient correlations among items to proceed with factor analysis.

\begin{tabular}{|c|c|c|c|}
\hline \multicolumn{2}{|l|}{ Characteristics } & $\begin{array}{l}\text { EFA } \\
\text { Others (N }-5951) \\
\text { Participants (\%) }\end{array}$ & \multirow{2}{*}{$\begin{array}{l}\text { CFA } \\
\text { Tourism (N = 393) } \\
\text { Participants (\%) } \\
180(45.8)\end{array}$} \\
\hline F1. Gender & Male & $3481(58.5)$ & \\
\hline & Female & $2470(41.5)$ & $213(54.2)$ \\
\hline \multirow{2}{*}{ F3. Marital status } & with spouse & $3911(65.7)$ & $212(53.9)$ \\
\hline & without spouse & $1997(33.6)$ & $179(45.5)$ \\
\hline \multirow{7}{*}{ F9.Education } & Junior High School & $258(4.3)$ & $32(8.1)$ \\
\hline & High School & $2220(37.3)$ & $186(47.3)$ \\
\hline & Technical/Training School & $974(16.4)$ & $76(19.3)$ \\
\hline & Junior College & $523(8.8)$ & $24(6.1)$ \\
\hline & Technical junior college & $97(1.6)$ & $2(0.5)$ \\
\hline & University & $1752(29.4)$ & 73 (18.6) \\
\hline & Graduate school & $118(2.0)$ & $\mathrm{N} / \mathrm{A}$ \\
\hline \multirow[t]{7}{*}{ Q1.Employment } & Full-time & $4185(70)$. & $165(42)$ \\
\hline & Contract & $212(3.6)$ & $13(3.3)$ \\
\hline & Part-time (hourly) & $259(4.4)$ & $68(17.3)$ \\
\hline & Part-time & $1084(18.2)$ & $142(36.1)$ \\
\hline & Dispatch & $134(2.3)$ & $3(0.8)$ \\
\hline & Outsourcing (one company exdusive) & $55(0.9)$ & $1(0.3)$ \\
\hline & Outsourcing (several companies) & $22(0.4)$ & $1(0.3)$ \\
\hline \multirow[t]{4}{*}{ Q6.Sector } & Others & $5951(100)$ & $\mathrm{N} / \mathrm{A}$ \\
\hline & Services instrumental to travel and transportation $\left(35^{\circ}\right)$ & $\mathrm{N} / \mathrm{A}$ & $33(8.4)$ \\
\hline & Dinning/eateries $\left(51^{\circ}\right)$ & $\mathrm{N} / \mathrm{A}$ & $310(78.9)$ \\
\hline & Inns, hotels, leisure (52) & $\mathrm{N} / \mathrm{A}$ & $50(12.7)$ \\
\hline
\end{tabular}

Source: Working Per son Survey 2008, N/A = not applicable.

Original numbering.

Using the Eigenvalue criterion ( $>1.0)$ the derived pattern matrix revealed a 16 -item, six-factor structure (Table 3, in bold) with loadings of $|.50|$ or greater on a single factor (Hair et al., 2014; p. 115). However, it is recommended that at least three to four items representing each common factor be included in a study (see Hair et al., 2014; p. 608). Therefore, factors 5 and 6 were omitted from further analysis. The internal consistency of the remaining four factors, measured with Cronbach's alpha coefficients, was above the lower limit of acceptability (0.60 to 0.70; Hair et al., 2014; p. 90), ranging from 0.67 to 0.78 .

More importantly, the content of each of the four factors corroborates the proposed conceptualisation of work values. In particular, the items that comprised Factor 1 (personal fulfilment, accomplishment, escape from routine and doing a job I want to do) are clearly associated with an inherent psychological satisfaction of working, illustrating an intrinsic type of work values. The composition of Factor 2 (directing people, authority and high profile job) illustrates a prestige type, whereas Factor 3 (high salary, understanding boss and opportunities for raise) comprised concrete and practical aspects of work, denoting an extrinsic type. Factor 4 includes items (affection to the company, staying in one company, friendly relationships with coworkers) related to an affective or social type of work values.

\section{Confirmatory factor analysis}

Following Hair et al. (2014), we constructed the model (Model 1, hereafter; Fig. 2) such that: (1) the thirteen items loaded 0.50 and greater onto the four factors identified in the EFA, which were represented as first-order factors with one second order factor (overall work-values); (2) covariance among the first-order factors was fully explained by their regression on the second-order factor; (3) each of the thirteen items (work aspects and outcomes) had a non-zero loading on its designated factors and zero loadings on other factors; and (4) the measurement error terms associated with the items were uncorrelated.

Four cases with "no answer" selected in at least one of the thirteen items were detected and deleted. Although the relevant AMOS test revealed univariate normality, the results indicated a departure of multivariate normality in the sample of 466 (Mardia's coefficient of multivariate kurtosis $=29.875$, critical ratio $=16.375$ ). Using 
the value of the squared Mahalanobis distance $(\mathrm{p}<0.05)$ we removed the cases with the largest contribution to Mardia's coefficient (outliers) until we reached multivariate normality (critical ratio $=1.912<|1.96|$ ). The final sample size of 393 is in line with Hair et al.'s (2014, p. 583) recommendations (i.e., $\mathrm{N}$ of 100 to 400) for using maximum likelihood estimation and has an adequate participants per measured item ratio (above 30).

Table 3

Pattern matrix of work values $(\mathrm{N}=5951)$.

\begin{tabular}{|c|c|c|c|c|c|c|}
\hline \multirow[t]{2}{*}{ Work aspects and outcomes } & \multicolumn{6}{|c|}{ Factors } \\
\hline & 1 & 2 & 3 & 4 & 5 & 6 \\
\hline Q19.27: Accomplishment & .63 & & & & & \\
\hline Q19.26: Per sonal fulfilment & .57 & & & & & \\
\hline Q19.28: Escape routine & .56 & & & & & \\
\hline Q19.29: Doing a job I want to do & .55 & & & & & \\
\hline Q19.21: Recognition & .46 & & & & & \\
\hline Q19.22: New challenges & .41 & & & & & .35 \\
\hline \multicolumn{7}{|l|}{ Q21.02: Personal development } \\
\hline Q19.20: Directing others & & .68 & & & & \\
\hline Q19.01: Authority & & .58 & & & & \\
\hline Q19.11: High profile job & & .56 & & & & \\
\hline Q19.24: High profile company & & .49 & & & & \\
\hline Q19.10: Respected & & .30 & & & & \\
\hline \multicolumn{7}{|l|}{ Q21.01: Working abroad } \\
\hline \multicolumn{7}{|l|}{ Q19.04: Initiative } \\
\hline Q19.15: Salary increase & & & .65 & & & \\
\hline Q19.14: Understanding boss & & & .60 & & & \\
\hline Q19.05: High salary & & & .55 & & & \\
\hline Q19.08: Comfortable environment & & & .49 & & & \\
\hline Q19.23: Convenient working hour and location & & & .49 & & & \\
\hline Q19.02: Competent boss & & & .41 & & & \\
\hline \multicolumn{7}{|l|}{ Q19.12: Refusal } \\
\hline Q19.18: Belonging to the company & & & & -0.69 & & \\
\hline Q19.19: Staying in one company & & & & -0.55 & & \\
\hline Q19.17: Relationship with co-workers & & & & -0.50 & & \\
\hline Q19.30: Useful to society & & & & & .83 & \\
\hline Q19.06: Contribution to society & & & & & .77 & \\
\hline Q19.25: Making people happy & 30 & & & & .46 & \\
\hline Q19.03: Ingenuity & & & & & & .50 \\
\hline Q19.07: New knowledge & & & & & & .45 \\
\hline Q19.16: New products and services & & & & & & .37 \\
\hline \multicolumn{7}{|l|}{ Q19.13: Aesthetic } \\
\hline Q19.09: Different types of work & & & & & & \\
\hline
\end{tabular}

are not displayed.

Hair et al. (2014; p. 637) recommend that the adequate congruence between the model and the underlying data should be assessed with a combination of fit statistics, including the chi square $(\chi 2)$ goodness-of-fit statistic and the degrees of freedom, one absolute fit index such as the goodness-of-fit index (GFI) or the standardised root mean square residual (SRMR), and one incremental fit index, such as the TuckerLewis Index (TLI) or the comparative fit index (CFI) whereas, one of these indices should also be a badness-of-fit indicator such as the SRMR or the root mean square error of approximation (RMSEA). Following recent CFA studies (i.e., Boley, McGehee, Perdue, \& Long, 2014; Wang, 2017; Yolal, Gursoy, Uysal, Kim, \& Karacaog lu, 2016) in addition to $\chi 2$ and the degree of freedom we assessed model fit using CFI, SRMR and RMSEA. Some of the criteria proposed from methodologists regarding the ideal model fit are a close to 0.95 value for CFI in combination with a cut-off value close to 0.09 for SRMR (Hu \& Bentler, 1999; p. 27) and a 0.70 for RMSEA (Steiger, 2007; p. 897).

The value of the $\chi 2$ was high and significant ( $\mathrm{v} 2=196.001$, $\mathrm{df}=61, \mathrm{p}=0.000$ ) and combined with a 0.075 value for RMSEA (the $90 \%$ confidence interval ranged from 0.064 to 0.087 ), a 0.927 for CFI and a 0.059 for SRMR indicated that the structure derived from the EFA may needed further modification to achieve a better fit. A possible explanation could be found in the examination of the standardized residuals covariance matrix. Items associated with a residual greater than $|2.5|$ should raise a concern as they suggest a potentially unacceptable degree of error (Hair et al. 2014, p. 621). 


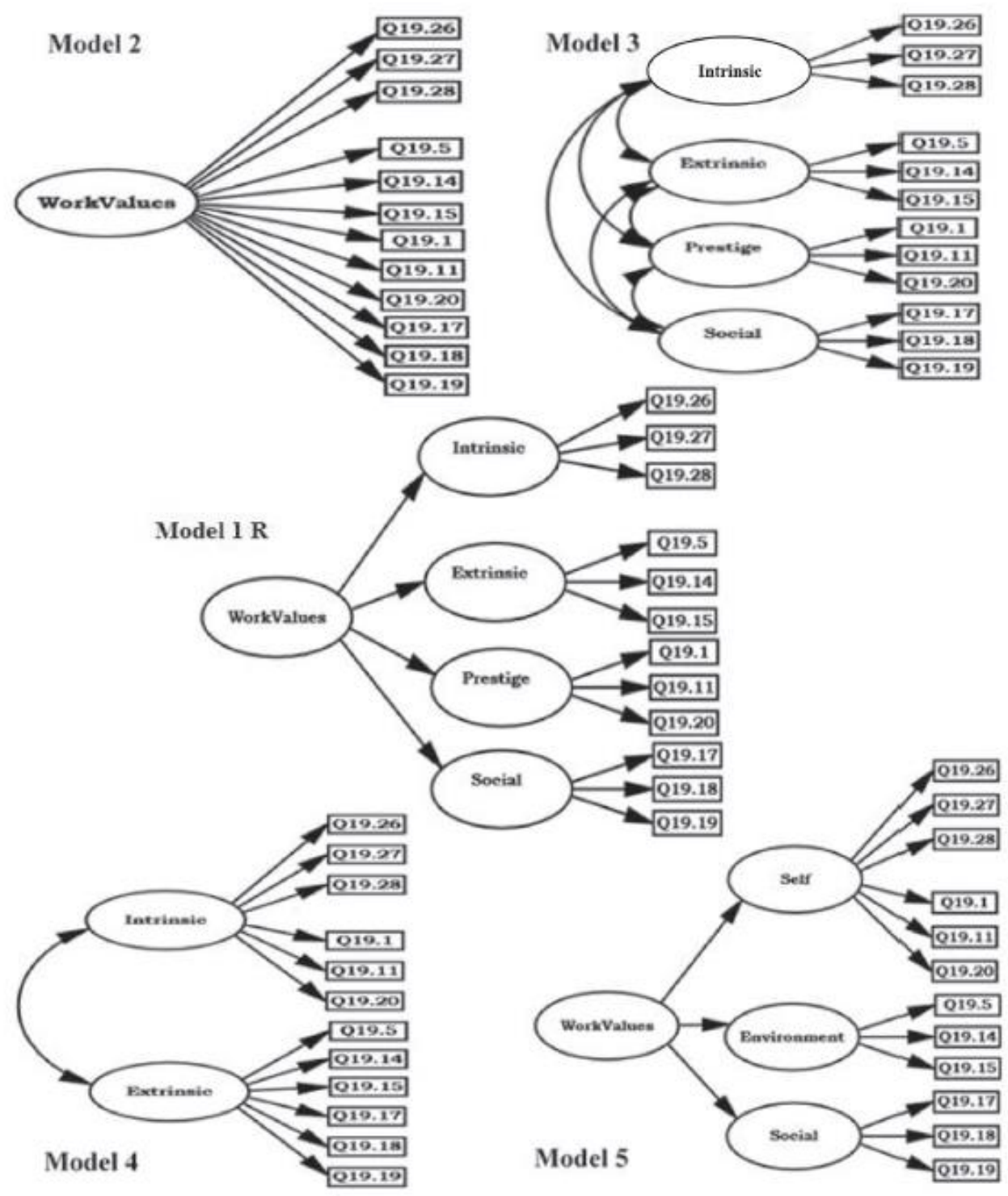

Fig. 2 Competing models of work values.

Table 4

CFA results (Model 1R)

\begin{tabular}{llllllllll}
\hline & 1 & 2 & 3 & 4 & Means & SD & CR & SMC & AVE \\
\hline 1. Social & 0.71 & & & & 2.19 & 0.64 & 0.75 & 0.53 & 0.50 \\
2. Prestige & 0.45 & 0.69 & & & 3.02 & 0.72 & 0.75 & 0.39 & 0.48 \\
3. Extrinsic & 0.52 & 0.45 & 0.72 & & 1.97 & 0.61 & 0.76 & 0.51 & 0.51 \\
4. Intrinsic & 0.61 & 0.53 & 0.60 & 0.77 & 2.15 & 0.67 & 0.81 & 0.70 & 0.59
\end{tabular}

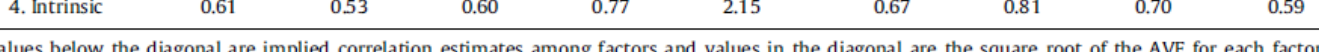
SD - Standard deviation; CR = Composite reliability; SMC = Square multiple correlation and AVE = average variance extracted.

Table 5

Model fit comparisons.

\begin{tabular}{lllll}
\hline & CFI & RMSEA & SRMR & AIC \\
\hline Model 1R (2nd order - 4 factors) & .941 & .069 & .054 & 200.470 \\
Model 2 (One factor) & .714 & .148 & .917 & 563.212 \\
Model 3 (1st order - 4 factors) & .940 & .071 & .054 & 204.064 \\
Model 4 (intrinsic/extrinsic) & .782 & .127 & .083 & 521.465 \\
Model 5 (2nd order - 3 factors) & .814 & .121 & .125 & 4037.263 \\
\hline
\end{tabular}

We deleted Q19.29 because of its association with two items (Q19.19 (|2.7|) and Q19.14 (|2.6|)). No further action was taken in order to retain three indicators variables per construct (i.e., the three indicator rule; Hair et al., 2014; p. 636). As noted by Hair et al. (2014, p. 621) it may be acceptable to retain one or more of these large residuals if no other problems are associated with those two items. In our case, the revised 12-item model, (Model 1R, hereafter) reveals a better fit closer to the 
criteria described by $\mathrm{Hu}$ and Bentler (1999) and Steiger (2007). In particular, the values of the CFI, SRMR and RMSEA, were improved to 0.941, 0.055 and 0.069, respectively (the $90 \%$ confidence interval ranged from 0.056 to 0.083 ). The value of the chi square was also improved but it remained high and significant (v2 $=144.470$, $\mathrm{df}=50, \mathrm{p}=0.000$ ). However, the values of the chi square vary from situation to situation and depend considerably on the sample size, number of measured variables and the communalities of the factors (Hair et al. 2014; p. 637) and in cases such as ours significant values may be expected (Hair et al., 2014, p. 584).

Construct reliability, as measured by Raykov's coefficient (Raykov, 1997) was also adequate, with values ranging from 0.75 to 0.81 for the first-order factors (Table 4) and 0.82 for the second-order factor. In addition, the standardised loading of one of the items to its designated factor was 0.59 , whereas the loadings of the remaining twelve were above 0.60 with half of them above 0.70 , providing evidence of construct validity (Hair et al., 2014; 605). The average variance extracted (AVE), calculated by averaging the squared multiple correlations for the first-order indicators (MacKenzie, Podsakoff, \& Podsakoff, 2011; A2) in each factor was 0.50 or greater as recommended for adequate convergent validity (Hair et al., 2014; p. 605) with the exception of the prestige factor (.48) (Table 4). This is not viewed as problematic in light of the accomplished discriminant validity, since the square root of the AVE for each factor was above 0.50 and much larger than the correlation (implied) of the specific factor with any of the other factors in the model (Gehen \& Straub, 2005; p. 94) (Table 4) and the adequate reliability and factor loadings.

\section{Comparing structurally and theoretically competing models}

Wong and Wan (2013) recommend that second-order models be compared against two structurally competing models; the baseline model (Model 2 hereafter, Fig. 2) which assumes that all variables (in this case the 16 work values items) are loaded on a single work value factor and the equivalent first-order four factor model (Model 3 hereafter, Fig. 2). We added the comparison of two other theoretically competing models: the dichotomisation model (Model 4 hereafter, Fig. 2), in which work values are divided into extrinsic and intrinsic aspirations (as per self-determination theory) and the trichotomisation model (Model 5 hereafter, Fig. 2), which assumes that work values is a second-order construct of needs related to self, social and the environment (as per the theory of work adjustment). Accordingly, Model 4 was developed by adding the items of (a) the prestige factor into the intrinsic factor and (b) the social factor into the extrinsic. Similarly, Model 5 was developed by adding the items of the prestige factor into the intrinsic as a means of reflecting the essence of self needs. The social and environment related needs were represented by the social and extrinsic factors, respectively. Table 5 illustrates that Model 1R demonstrated the best fit statistics in all absolute and incremental indices. Furthermore, the Akaike's information criterion, a parsimony fit index was lower for Model 1R (AIC=200.470).

\section{Conclusion}

This study provides a reconceptualised work values typology and makes a five-fold contribution to tourism research: First, we have provided an up-to-date review of the literature covering a period from 1979 to 2015. Second, the dominant conceptualisation of work values as expressions of values in tourism work setting has been critiqued and rationalised using a synthesis of paradigms pertaining to established value models and theories. We identified, two previously underdeveloped features of Schwartz's (1992) universally accepted theory of basic human value, the ordering by relative importance and the transcendental nature of values, and analysed their significance in reconceptualising work values in tourism. The 
proposed model has a greater explanatory capability and relevance to the tourism work setting by demonstrating both the presence of a hierarchically organised values system and the relationship between general life values and work values.

Third, we acknowledge that the contribution of a conceptualisation depends not merely on its meaningfulness and theoretical coherence but also on its relevance and applicability - namely whether the concept is valid (Baruch, 2014). Therefore, extending current approaches in reconceptualisation (i.e., Reisinger \& Steiner, 2006; Russo \& Serge, 2009; Tribe \& Liburd, 2016) we provide evidence of conceptual validity by means of CFA using a sample of workers from Japan. More importantly, compared to structurally and theoretically competing models our conceptualisation revealed a better fit.

Work values represent an organizing construct (Lyons et al., 2010), which, unlike more focused constructs, measure a broad psychological phenomenon by examining patterns among a theoretically limitless number of work-related indicators (Pryor, 1979; Shye, Elizur, \& Hoffman, 1994). In this way, it is similar to the construct of personality, which is represented by a seemingly infinite number of descriptive individual traits. The goal with such a construct is to identify a set of "marker" items that reliably represent broader categories of work aspects (Lyons et al., 2010). The model of work values that we have developed and tested here demonstrates a set of 12 work aspects representing four broader categories of work values relevant to the tourism sector.

The items representing each of the four types of work values are in keeping with conceptualisations in the broader work values literature (e.g., Sagie \& Elizur's, 1996; Lyons et al., 2010; Ros et al., 1999). Specifically, the three intrinsic work value items (Q19.26 - fulfilment; Q19.27 - accomplishment; and Q19.27 - escaping routine) all link into aspects of psychological rewards of tourism work and are in keeping with conceptualisations of intrinsic or cognitive work values in the broader literature (e.g., Sagie \& Elizur's, 1996). Similarly, the three items representing extrinsic work values (Q19.5 - Salary; Q19.14 - Having an understanding boss; and Q15.14 - Salary increases) are indicative of instrumental aspects of working that address one's comfort and security needs (Ros et al., 1999). The three prestige work value items (Q19.1 - Authority; Q19.11 - High profile job; and Q19.20 - Directing others) all represent elements of the type of power or prestige work values that address one's self-enhancement needs (Ros et al., 1999). Finally, three work value items relate to the social aspect of work (Q19.17 - Coworkers; Q19.17 - Sense of belonging in the company; and Q19.19 - Staying in one company), addressing one's need for affiliation and relationships with colleagues (Sagie \& Elizur's, 1996) and a sense of contributing to a greater collective (Ros et al., 1999).

Fourth, Gursoy et al.'s (2013) notion that work values emerge from the projection of general values onto the domain of work, is now theoretically developed using Sagie and Elizur's (1996) model. Furthermore, Chu's (2008) empirically developed second-order relationship between the types of work values has been theoretically supported using the theory of work adjustment (Dawis \& Lofquist, 1980) and empirically validated with a revised four-factor typology. This corroborates Pizam and associates' typology of self-expression (intrinsic), work conditions (extrinsic), status (prestige) and altruistic (social). Moreover, they represent work-related analogues to Schwartz's (1992) basic human value types as theoretically articulated by Ros et al. (1999).

Fifth, encouraged by Shaw, Bailey, and Williams (2011) and Bramwell (2015), who stressed the importance of engaging with wider debates in mainstream management 
literature, our study may have opened up the sometimes static and possibly stale tourism research praxis (Tribe \& Liburd, 2016). Since the introduction of the SWVI in 1970, the conceptualisation of work values remains a subject of debate in mainstream management (Gehman et al., 2013; Leuty \& Hansen, 2011; Lyons et al., 2010). Our study engaged with this debate through critique, synthesis, revision and extension of previous work, rather than an implied or taken for granted process.

Our model has practical implications for the recruitment, engagement, and retention of high-potential tourism workers. We now have a four-type scheme that provides common basis upon which new recruits can be assessed and matched for fit with the values of the organization. In particular, this scheme can be used to recruit, select and retain younger workers in tourism to replace the large cohort of Baby Boomers who are currently retiring (Gursoy et al., 2013). Research suggests that the younger generation of tourism workers are significantly more individualistic than were previous generations (Chen \& Choi, 2008; Gursoy et al., 2008; Gursoy et al., 2013). Broader generational research suggests that social and prestige work values are aligned with the individualism of the younger generations (Lyons \& Kuron, 2014; Parry \& Urwin, 2011). With this in mind, our model provides guidance as to how recruiting employers can target the individualistic work aspects that are most likely to resonate with younger workers. By the same token, it shows which work aspects are associated with the less individualistic values of the older generations. By emphasizing different work aspects in the recruitment and management of different generations, organizations can better satisfy the values of multiple cohorts. Our conceptualisation offers scholars and practitioners new ways of thinking about work values within tourism organisations.

\section{Acknowledgements}

We would like to acknowledge the Center for Social Research and Data Archives located at the University of Tokyo, Institute of Social Science for providing the 2008 WPS database as well as Dr. Akiko Sakamoto, Dr Kei Tsui and Yoshihide Yanagino, for helping with the translation.

\section{References}

Ashforth, B. E., Schinoff, B. S., \& Rogers, K. M. (2016). “I Identify with Her”, “I Identify with Him": Unpacking the dynamics of personal identification in organizations. Academy of Management Review, 41(1), 28-60.

Baruch, Y. (2014). The development and validation of a measure for protean career orientation. The International Journal of Human Resource Management, 25 (19), 2702-2723.

Baum, T., Kralj, A., Robinson, R. N., \& Solnet, D. J. (2016). Tourism workforce research: A review, taxonomy and agenda. Annals of Tourism Research, 60, 122.

Bizjak, B., Kneževic' , M., \& Cvetrežnik, S. (2011). Attitude change towards guests with disabilities: Reflections from tourism students. Annals of Tourism Research, 38(3), 842-857.

Boley, B. B., McGehee, N. G., Perdue, R. R., \& Long, P. (2014). Empowerment and resident attitudes toward tourism: Strengthening the theoretical foundation through a Weberian lens. Annals of Tourism Research, 49, 33-50.

Bramwell, B. (2015). Theoretical activity in sustainable tourism research. Annals of Tourism Research, 54, 204-218.

Chen, J. S., Hei-Lin Chu, K., \& Wu, W. C. (2000). Tourism students' perceptions of work values: a case of Taiwanese universities. International Journal of Contemporary Hospitality Management, 12(6), 360-365. 
Chen, P. J., \& Choi, Y. (2008). Generational differences in work values: a study of hospitality management. International Journal of Contemporary Hospitality Management, 20(6), 595-615.

Chen, P. J., \& Tesone, D. V. (2009). Comparison of hospitality practitioners and student/ practitioner work values. Advances in Hospitality and Leisure, 5, 141161.

Choi, M. J., Heo, C. Y., \& Law, R. (2015). Developing a typology of Chinese shopping tourists: An application of the Schwartz model of universal human values. Journal of Travel \& Tourism Marketing, 3, 1-21.

Chu, A. Z., \& Chu, R. J. (2013). Service willingness and senior tourists: Knowledge about aging, attitudes toward the elderly, and work values. The Service Industries Journal, 33(12), 1148-1164.

Chu, K. H. (2008). A factorial validation of work value structure: Second-order confirmatory factor analysis and its implications. Tourism Management, 29(2),

320-330.

Colquitt, J. A., \& Zapata-Phelan, C. P. (2007). Trends in theory building and theory testing: A five-decade study of the Academy of Management Journal. Academy of Management Journal, 50(6), 1281-1303.

Davidov, E., Schmidt, P., \& Schwartz, S. H. (2008). Bringing values back in the adequacy of the European Social Survey to measure values in 20 countries. Public Opinion Quarterly, 72(3), 420-445.

Dawis, R. V., \& Lofquist, L. H. (1980). A psychological theory of work adjustment: An individual-differences model and its applications. Minneapolis: University of Minnesota Press.

de Vaus, D., \& McAllister, I. (1991). Gender and work orientation: Values and satisfaction in Western Europe. Work and Occupations, 18(1), 72-93.

Fabrigar, L. R., Wegener, D. T., MacCallum, R. C., \& Strahan, E. J. (1999). Evaluating the use of exploratory factor analysis in psychological research. Psychological Methods, 4(3), 272-299.

Figueroa-Domecq, C., Pritchard, A., Segovia-Pérez, M., Morgan, N., \& VillacéMolinero, T. (2015). Tourism gender research: A critical accounting. Annals of

Tourism Research, 52, 87-103.

Gefen, D., \& Straub, D. (2005). A practical guide to factorial validity using PLSGraph: Tutorial and annotated example. Communications of the Association for Information systems, 16(1), 91-109.

Gehman, J., Trevino, L. K., \& Garud, R. (2013). Values work: A process study of the emergence and performance of organizational values practices. Academy of Management Journal, 56(1), 84-112.

Gursoy, D., Chi, C. G.-Q., \& Karadag, E. (2013). Generational differences in work values and attitudes among frontline and service contact employees. International Journal of Hospitality Management, 32, 40-48.

Gursoy, D., Maier, T. A., \& Chi, C. G. (2008). Generational differences: An examination of work values and generational gaps in the hospitality workforce. International Journal of Hospitality Management, 27(3), 448-458.

Hair, J., Black, W. C., Babin, B. J., \& Anderson, R. E. (2014). Multivariate data analysis: Pearson new international edition. Upper Saddle River. New Jersey: Pearson.

Hofstede, G. (1980). Culture's consequences: International differences in workrelated values. Newbury Park, CA: Sage.

Holbrow, H. J. (2015). How conformity to labor market norms increases access to job search assistance: A case study from Japan. Work and Occupations, 42(2), $135-173$.

Hu, L. T., \& Bentler, P. M. (1999). Cutoff criteria for fit indexes in covariance structure analysis: Conventional criteria versus new alternatives. Structural Equation Modeling: A Multidisciplinary Journal, 6(1), 1-55. 
Jin, J., \& Rounds, J. (2012). Stability and change in work values: A meta-analysis of longitudinal studies. Journal of Vocational Behavior, 80(2), 326-339.

Kline, R. B. (2011). Principles and practice of structural equation modeling. New York, NY: The Guilford Press.

Koroglu, O., \& Gezen, T. (2014). An Investigation to Determine the Work Values of Tourism Students. Procedia - Social and Behavioral Sciences, 131, 253-257.

Ladkin, A. (2011). Exploring tourism labour. Annals of Tourism Research, 38(3), $1135-1155$.

Leuty, M. E., \& Hansen, J. C. (2011). Evidence of construct validity for work values. Journal of Vocational Behavior, 79(2), 379-390.

Liang, Y.-W. (2012). The relationships among work values, burnout, and organizational citizenship behaviors: A study from hotel front-line service

employees in Taiwan. International Journal of Contemporary Hospitality Management, 24(2), 251-268.

Lyons, S. T., Higgins, C., \& Duxbury, L. (2010). Work values: Development of a new three dimensional structure based on confirmatory smallest space analysis. Journal of Organizational Behavior, 31, 969-1002.

Lyons, S., \& Kuron, L. (2014). Generational differences in the workplace: A review of the evidence and directions for future research. Journal of Organizational Behavior, 35(S1), S139-S157.

MacKenzie, S. B., Podsakoff, P. M., \& Podsakoff, N. P. (2011). Construct measurement and validation procedures in MIS and behavioral research: Integrating new and existing techniques. MIS Quarterly, 35(2), 293-334.

Mok, C., Pine, R., \& Pizam, A. (1998). Work values of Chinese hotel managers. Journal of Hospitality \& Tourism Research, 21(3), 1-16.

Super, D. E., \& Nevill, D. D. (1986). The salience inventory. Consulting Psychologists Press.

Neuman, Y., Pizam, A., \& Reichel, A. (1980). Values as determinants of motivation in Tourism and other career choices. Annals of Tourism Review, 3, 428-442.

Phillips, P., \& Moutinho, L. (2014). Critical review of strategic planning research in hospitality and tourism. Annals of Tourism Research, 48, 96-120.

Parry, E., \& Urwin, P. (2011). Generational differences in work values: A review of theory and evidence. International Journal of Management Reviews, 13(1), 7996.

Pilavcy' , D. (2007). Evolving and changing career concept in the information age and an investigation of the factors influencing the career preferences of undergraduates Master Thesis. Adana, Turkey: Çukurova University Department of Business Administration.

Pizam, A., \& Lewis, R. C. (1979). Work values of hospitality students. Journal of Hospitality \& Tourism Research, 3(2), 5-16.

Pizam, A., Reichel, A., \& Neumann, Y. (1980). The motivational profile and work values of hospitality students. Journal of Hospitality \& Tourism Research, 5(1), 25-38.

Pryor, R. G. L. (1979). In search of a concept: Work values. The Vocational Guidance Quarterly, 27, 250-258.

Pryor, R. (1983). Manual of the Work Aspect Preference Scale. Melbourne, Australia: Australian Council for Educational Research.

Ravlin, E. C., \& Meglino, B. M. (1989). The transitivity of work values: Hierarchical preference ordering of socially desirable stimuli. Organizational Behavior and Human Decision Processes, 44(3), 494-508.

Raykov, T. (1997). Estimation of composite reliability for congeneric measures. Applied Psychological Measurement, 21(2), 173-184.

Reisinger, Y., \& Steiner, C. (2006). Reconceptualising object authenticity. Annals of Tourism Research, 33(1), 65-86. 
Rohan, M. J. (2000). A rose by any name? The values construct. Personality and Social Psychology Review, 4(3), 255-277.

Rokeach, M. (1973). The nature of human values. Free press.

Ros, M., Schwartz, S. H., \& Surkiss, S. (1999). Basic individual values, work values, and the meaning of work. Applied Psychology, 48(1), 49-71.

Ross, G. F. (1992). Tourism and hospitality industry job-attainment beliefs and work values among Australian schools leavers. International Journal of Hospitality Management, 11(4), 319-330.

Russo, A., \& Segre, G. (2009). Destination models and property regimes: An exploration. Annals of Tourism Research, 36(4), 587-606.

Ryan, R. M., \& Deci, E. L. (2000). Self-determination theory and the facilitation of intrinsic motivation, social development, and well-being. American Psychologist, $55,68-78$.

Sagie, A., \& Elizur, D. (1996). The structure of personal values: A conical representation of multiple life areas. Journal of Organizational Behavior, 17, $573-586$.

Schwartz, S. H. (1992). Universals in the content and structure of values: Theoretical advances and empirical tests in 20 countries. Advances in Experimental Social Psychology, 25(1), 1-65.

Shaw, G., Bailey, A., \& Williams, A. (2011). Aspects of service-dominant logic and its implications for tourism management: Examples from the hotel industry. Tourism Management, 32(2), 207-214.

Shaw, G., \& Williams, A. M. (2009). Knowledge transfer and management in tourism organisations: An emerging research agenda. Tourism Management, 30, 325-335.

Shye, S., Elizur, D., \& Hoffman, M. (1994). Facet theory. Newbury Park, CA: Sage.

Solnet, D., Kralj, A., \& Baum, T. (2015). 360 degrees of pressure: the changing role of the HR professional in the hospitality industry. Journal of Hospitality \& Tourism Research, 39(2), 271-292.

Steiger, J. H. (2007). Understanding the limitations of global fit assessment in structural equation modeling. Personality and Individual Differences, 42(5), 893898.

Super, D. E. (1970). Work values inventory: Manual. Riverside Publishing Company.

Toda, A. (2016). Understanding restricted regular employment: Differences by company size with a focus on wages and satisfaction levels. Japan Labor Review, 13(2), 70-87.

Tribe, J., \& Liburd, J. J. (2016). The tourism knowledge system. Annals of Tourism Research, 57, 44-61.

Vizek-Vidovic, V., Kulenovic, A., Jerneic, Z., \& Sverko, B. (1984). Hierarchies of work values among pupils, students and employees. Primjenjena Psihologija, 5, $166-173$.

Wang, S. (2017). Leisure travel outcomes and life satisfaction: An integrative look. Annals of Tourism Research, 63, 169-182.

White, C. (2005). The relationship between cultural values and individual work values in the hospitality industry. International Journal of Tourism Research, 7(4-5), 221-229.

White, C. (2006). Towards an understanding of the relationship between work values and cultural orientations. International Journal of Hospitality Management, 25(4), 699-715.

Wong, C. K., \& Chung, K. H. (2003). Work values of Chinese food service managers. International Journal of Contemporary Hospitality Management, 15(2), 66-75.

Wong, C.-K. S., \& Liu, J. G. (2009). Work values and their relationships with career choice: A segment-based approach to understanding hospitality and tourism management students in China. Journal of China Tourism Research, 5(4), 339363. 
Wong, I. A., \& Wan, Y. K. P. (2013). A systematic approach to scale development in tourist shopping satisfaction linking destination attributes and shopping experience. Journal of Travel Research, 52(1), 29-41.

Yolal, M., Gursoy, D., Uysal, M., Kim, H. L., \& Karacaog `lu, S. (2016). Impacts of festivals and events on residents' well-being. Annals of Tourism Research, 61, 118.

Xin, S., Tribe, J., \& Chambers, D. (2013). Conceptual research in tourism. Annals of Tourism Research, 41, 66-88.

Appendix - Work values assessment (WPS 2008)

Question: How important are the following factors for you in your work? (This question concerns not only your current job but your career in general)

Options: (1) It is very important, (2) It is important, (3) It is somehow important, (4), It is not very important, (5) It is not important, (6) No answer

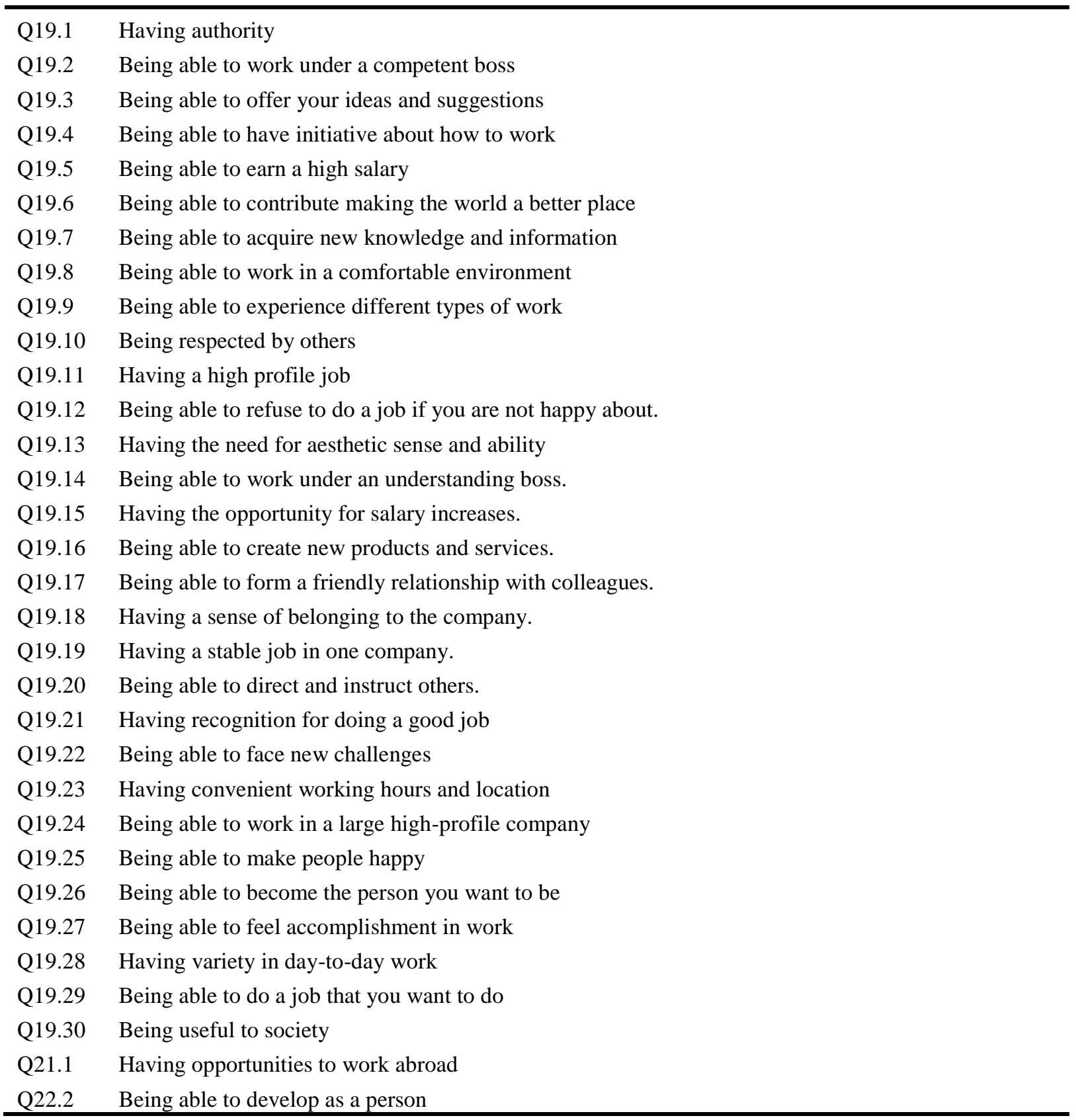

